\title{
The antimicrobial and antioxidant properties of garagurt: traditional Cornelian cherry
}

\section{(Cornus mas) marmalade}

\author{
E. Savaș ${ }^{1 *}$, H. Tavşanlı ${ }^{2}$, G. Çatalkaya ${ }^{3}$, E. Çapanoğlu ${ }^{3}$ and C. E. Tamer ${ }^{3}$ \\ ${ }^{1}$ Department of Food Engineering, Faculty of Engineering, Balikesir University, Cagis 10147, Balikesir, Turkey; ${ }^{2}$ Food \\ Hygiene Department of Veterinary Faculty, Balikesir University; ${ }^{3}$ Food Engineering Department of Chemical and \\ Metallurgical Engineering, Istanbul Technical University and Food Engineering Department of Agriculture Faculty, \\ Uludag University, 16059, Grükle BURSA
}

Corresponding Author: E. Savaş, esavas@balikesir.edu.tr

Received: 1 November 2019 / Accepted: 11 March 2020 / Published: 22 April 2020

(c) 2020 Codon Publications

OPEN ACCESS Cc) ORIGINAL ARTICLE

\begin{abstract}
The traditional Cornelian cherry marmalade, named as 'Garagurt', is usually consumed for nutritional purposes and health benefits. The objective of this study was to determine the antimicrobial and antioxidant activities of Cornelian cherry marmalade. Antioxidant activities of the sample as determined by ABTS, cupric ion-reducing antioxidant capacity (CUPRAC) and 1,1-diphenyl-2-picryl-hydrazyl (DPPH) assays were 8,428 $\pm 1,206 \mathrm{mg}$ TE/100 $\mathrm{g}, 1,599 \pm 41.4 \mathrm{mg} \mathrm{TE} / 100 \mathrm{~g}$ and $773 \pm 206 \mathrm{mg}$ TE$/ 100 \mathrm{~g}$ respectively. The antimicrobial activity of the sample was determined by the disc diffusion method in minimum inhibitory concentration (MIC) against Listeria monocytogenes, Bacillus cereus, Staphylococcus aureus, Escherichia coli, Escherichia coli O157:H7, Salmonella typhimurium, Pseudomonas fluorescens and Yersinia enterocolitica. The MIC value of garagurt ( $0.66 \mathrm{mg}$ phenol compound/g) was $\geq 256 \mathrm{mg} / \mathrm{mL}$ for L. monocytogenes, S. aureus, Y. enterocolitica, E. coli and P. fluorescens when gentamicin $(10 \mu \mathrm{g})$ was used as positive control. Total phenolic content (TPC), which provides antimicrobial and antioxidant activities, was determined as $195 \pm 6.35 \mathrm{mg}$ GAE/100 g in aqueous methanolic extract of garagurt. This product in different forms could be used for its antimicrobial effect to increase the shelf life of different foods.
\end{abstract}

Keywords: Cornus mas, marmalade, antioxidant activity, antimicrobial activity

\section{Introduction}

Diseases originating from oxidative damage, such as cancer, coronary insufficiency, arthritis and diabetes, neurodegenerative diseases, such as Alzheimer's and Parkinson's, and many other diseases as well as signs of aging could be prevented or delayed by consumption of natural nutrients with high antioxidant contents (Dinda et al., 2016; Hosseinpour-Jaghdani et al., 2017; Moldovan et al., 2017; Polat et al., 2013; Shahidi and Naczk, 1995; Szumny et al., 2015; Zargari, 1996, 1997). In this sense, several wild fruits with high levels of phytochemicals are becoming more and more important. Many of them are consumed as fresh, but they are also processed and preserved by different methods for off-season consumption. Production of jams or marmalades is one of the traditional processing methods used in Anatolia. This method is based on concentrating the fruit pulp with or without addition of sugar. Several wild fruits can be used for marmalade production, including Cornelian cherry (Şengül et al., 2018). Cornelian cherry (Cornus mas L.) is a temperate climate fruit growing in Anatolia and is commonly found as shrubs in coastal areas. It grows in wide geographic areas such as the south and southwest Asia and the temperate regions of the Northern Hemisphere (Çelik, 2009; Moldovan et al., 2017; Şengül et al., 2018). It has a sour taste and intense flavour, red in colour and oval in shape similar to olive. Cornelian cherry is highly tolerant to 
different environmental conditions, pests and diseases. Growing successfully in natural conditions without the use of pesticides makes this fruit suitable for organic production (Bijelić et al., 2011; Drkenda et al., 2014). The production of Cornelian cherry in Turkey in 2017 was 10,012 tons from 699,422 trees (Turkish Statistical Institute (TUIK), 2018). On the other hand, the number of Cornelian cherry trees is reducing because of the low commercial value of fruits. Tontul et al. (2018) recommended the processing of value-added products for the sustainability of this fruit.

The chemical composition of the fruit depends on the genotypes and its propagation in a geographical location (Dinda et al., 2016). For instance, 13 cultivars of Cornelian cherry fruits from Artvin, Turkey, were reported to contain $13.7-18.6 \%$ soluble solids, $31-70 \mathrm{mg} / 100 \mathrm{~g}$ vitamin C, $0.75-2.18 \%$ total protein, $0.36-1.08 \%$ cellulose, 0.57-1.28\% tannin and 0.51-1.13\% total ash (Ercisli et al., 2011); 24 cultivars of Cornelian cherry fruits from Samsun, Turkey, were indicated to have $16-88 \mathrm{mg} / 100 \mathrm{~g}$, fresh weight (FW) of vitamin C; 112-292 mg/100 g, FW of anthocyanins and 7.7-16.4 g/100 g, FW of sugars (Tural and Koca, 2008); 16 cultivars of Cornelian cherry fruits from Western Black Sea and inner Anatolia, Turkey, were reported to contain $29-112 \mathrm{mg} / 100 \mathrm{~g}$, FW vitamin C, 148-237 mg/100 g, FW anthocyanins and 2.8-7.0 g/100 g, FW reducing sugars (Yilmaz et al., 2009); 5 cultivars of Cornelian cherry fruits from Czech Republic were analysed to have $19.9-43.3 \mathrm{mg} / 100 \mathrm{~g}$, FW vitamin C and $6.1-25.3 \mathrm{mg} / 100 \mathrm{~g}$, FW anthocyanins (Cetkovska et al., 2014). On the other hand, the phenolic, anthocyanin and tannin contents of Cornelian cherry fruits were found to depend on the ripeness of fruits; and the bluish stage of fruits show the highest phenolic and anthocyanin contents (Gunduz et al., 2013). The above-mentioned physicochemical data on Cornelian cherry fruits show their high contents of phytochemicals (Dinda et al., 2016). Major minerals contained in the fruits are established as potassium (K) (14300.984 ppm), calcium (Ca) (1560.095 $\mathrm{ppm})$, magnesium $(\mathrm{Mg})$ (715.231 ppm), phosphorus (P) (605.558 ppm) and sulphur (S) (436.754 ppm) (Kalyoncu et al., 2009).

Phytochemicals such as flavonoids, phenolics, carotenoids and vitamins are very important nutritional compounds for human health (Bernal et al., 2011; Kubola et al., 2011; Rangkadilok et al., 2007; Mustafa et al., 2012). These compounds exhibiting antioxidant, anticarcinogen, antimutagen and antimicrobial activities are known for their positive effects on health and therefore used for phytotherapy (Coşkun, 2006; Vareed et al., 2006). Phenolics (i.e. gallic acid, ellagic acid, catechins, $p$-coumaric acid, rutin, quinones, flavonoids, coumarins and tannins) are very important for antimicrobial activities as well as antioxidative effects (Rangkadilok et al., 2007; Şengün and Yücel, 2015; Turaland Koca, 2008).
In addition to strong antioxidants such as phenolic acids (Ercisli et al., 2011; Kucharska, 2012; Serteser et al., 2009), flavonoids (David and Moldovan, 2015; Pawlowska et al., 2010; Yllmaz et al., 2009) and vitamin C, Cornelian cherry also contains organic acids (Kucharska et al., 2011; Seeram et al., 2002) terpenoids (Güneș et al., 2016) and iridoids (Deng et al., 2013). Total phenolic and flavonoid contents and potent antioxidant activity are affected by the genotype of the fruit, variety, location, agronomic factors, post-harvest and storage processes. Mature Cornelian cherry fruits are utilised as food preservatives and for the treatment of diarrhoea and gastrointestinal diseases in traditional Turkish medicine (Celik et al., 2006). This wild fruit, which is protective against oxidative stress (Vardin et al., 2018), has got anti-allergic, antimicrobial, anti-inflammatory, antidiabetic, anti-obesity, anti-atherosclerotic, anticancer, hypolipidemic, hepatoprotective, neuroprotective, cardioprotective, diuretic and antimalarial properties (Alavian et al., 2014; Dinda et al., 2016; Hassanpour et al., 2011; Jayaprakasam et al., 2005; Moldovan et al., 2016a, 2016b; Popović et al., 2012; Vareed et al., 2006; Yilmaz et al., 2009). For determining biological activity and justifying the traditional use of Cornus species, the phytochemical composition was evaluated as an important factor (Czerwin'ska and Melzig, 2018). Xi et al. (2011) found that the use of Cornus mas powder in cured meat production at 1\%, $2 \%$ and 3\% levels reduced the number of Listeria monocytogenes by $2-4 \log \mathrm{cfu} / \mathrm{g}$. They studied the effect of Cornelian cherry and its products on seven different food pathogens (vancomycin-resistant E. faecium, E. coli, E. coli $\mathrm{O} 157: \mathrm{H} 7$, L. monocytogenes, $P$. aeruginosa, $S$. typhimurium and $S$. aureus) and indicated that the antimicrobial effect of phenolic fractions was reduced by the technological processing of Cornelian cherry juice (Côté et al., 2011; Wu et al., 2008).

Cornelian cherry has sweet-sour and slightly astringent taste. Fruits are consumed as fresh or used to produce jam, marmalade, fruit leather, pekmez (a kind of molasses), compotes, ice-cream, yogurt, chutney and several types of beverages, or are dried. Anthocyanins of the fruits could be used as natural food colourants (Bijelić et al., 2011; Kazimierski et al., 2019; Mohebbi et al., 2015; Moldovan and David, 2014; Ozgen, 2015; Topdaş et al., 2017; Tontul et al., 2018). In Turkey, sour Cornelian cherry concentrate is used for salad, in soup and as appetiser (Bozdogan, 2017; Çakmakçı and Tosun, 2010; Demir and Kalyoncu, 2003). Fresh fruits are ideal ingredients for cakes and desserts. Recently, attention has been drawn to the possibility of applying the pickling method for Cornelian cherry fruits to obtain what is known as Polish olives. Roasted Cornelian cherry seeds were also used for preparing coffee (Kazimierski et al., 2019).

Fruit preserves can be considered as important sources of phenolics with antioxidant capacity (Rosa et al., 2015). Jam and marmalade production is one of the preservation methods of these perishables. Garagurt is a traditional 
marmalade prepared from Cornelian cherry fruit in Balıkesir, Turkey. It has been consumed by local people for centuries for therapeutic effects against psoriasis, eczema and allergy problems and insulin resistance as well as cardiovascular diseases. Garagurt has a very long shelf life without the use of preservatives. It can be stored at room temprature for a long periods without microbial growth.

Within this context, the objective of this study was to determine the phenolic composition and antimicrobial and antioxidant properties of traditional garagurt marmalade for the first time.

\section{Materials and methods}

\section{Materials}

Traditional Cornelian cherry marmalade, named as 'garagurt', was obtained from Dursunbey district of Balıkesir province, Turkey. The following chemicals were obtained from Sigma-Aldrich $\mathrm{GmbH}$ in Sternheim, Germany: 2,2'-azino-bis(3-ethylbenzthiazoline-6-sulfonic acid) (ABTS); the stable free radical, DPPH; 3-(2-pyridyl)-5,6-bis (4-phenyl-sulphonic acid)-1,2,4-triazine (Ferrozine); linoleic acid; $\alpha$-tocopherol; polyoxyethylene sorbitan monolaurate (Tween-20) and trichloroacetic acid (TCA). The standards, including gallic acid ( $\geq 99 \%)$, ellagic acid (95\%), catechin ( $\geq 98 \%), p$-coumaric acid $(\geq 98.0 \%)$ and rutin ( $\geq 94 \%$ ), were of High-Performance Liquid Chromatography (HPLC) grade obtained from Sigma-Aldrich (Merck KGaA, Darmstadt, Germany).

\section{Production of traditional Cornelian cherry marmalade (garagurt)}

The production of garagurt is shown in Figure 1. Cornelian cherry fruits were collected from Dursunbey district of
Balıkesir province, Turkey. Fruits were washed after removal of stems and leaves. Fruits were boiled in tap water for $2 \mathrm{~h}$. The pulp was obtained after the separation of skin and core. It was concentrated by boiling for $6-8 \mathrm{~h}$ (no sugar was added). Then it was sun-dried, cooled and filled in glass jars.

\section{Physicochemical analysis of garagurt}

The specific gravity and total soluble solids ( ${ }^{\circ}$ Brix) in garagurt samples were measured using a digital refractometer (Mettler Toledo RE50, Switzerland). The $\mathrm{pH}$ was measured using a digital $\mathrm{pH}$ metre (Hanna, HI 2020-02, USD). The total acidity was determined by titrating with $0.1 \mathrm{~N}$ $\mathrm{NaOH}$ and expressed as citric acid equivalent. The total protein and ash contents were analysed according to the Association of Official Analytical Chemists (AOAC, 1990) procedures. Vitamin C content was determined by a UVVis Spectrophotometer (Thermo) according to the method of Uylaşer and Başoğlu (2016). The lightness (L), red/green coordinate (a) and yellow/blue coordinate (b) values were measured using a colorimeter (Spectrophotometer CM-5, Konica Minolta Sensing Europe B.V.).

\section{Extraction of traditional Cornelian cherry marmalade (garagurt)}

For the sample extraction to be further used for antioxidant assays, $10 \mathrm{~mL}$ of ethanol (60\%) was added to $2 \mathrm{~g}$ of marmalade. The mixture was homogenised using a vortex. Then the homogenised mixture was kept in ultrasonic bath for $15 \mathrm{~min}$, and centrifuged at 4,000 rpm $\left(+4^{\circ} \mathrm{C}\right)$ for $10 \mathrm{~min}$ and the obtained supernatant was separated. Then $10 \mathrm{~mL}$ of ethanol $(60 \% \mathrm{v} / \mathrm{v})$ was added to the remaining pellet and re-extracted as described previously. Supernatants obtained from both extractions were pooled and completed to $25 \mathrm{~mL}$ with aqueous ethanol

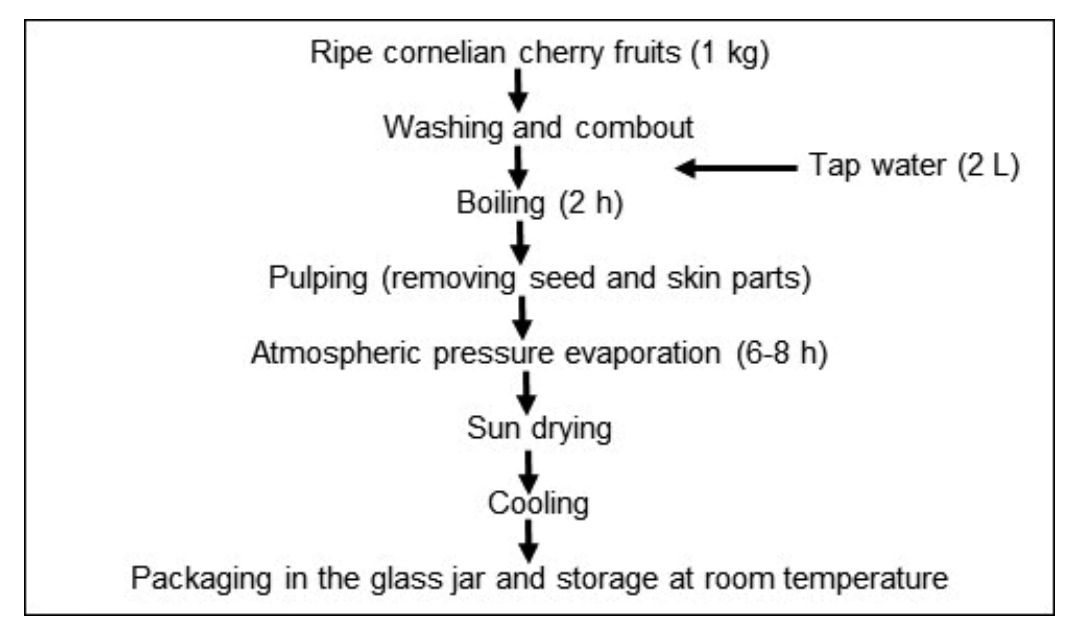

Figure 1. Production of traditional Cornelian cherry marmalade (garagurt). 
(Kamiloglu et al., 2015b). Three independent extracts were prepared from the marmalade sample and measured in triplicate during analyses.

\section{Determination of total phenolic content (TPC)}

The TPC was determined by the Folin-Ciocalteu (FC) method (Spanos and Wrolstad, 1990) with some modifications. Briefly, $0.75 \mathrm{~mL}$ of FC reagent was mixed with $100-\mu \mathrm{L}$ extract; after $5 \mathrm{~min}, 0.75-\mathrm{mL}$ saturated $\mathrm{Na}_{2} \mathrm{CO}_{3}$ solution was added and the mixture was kept for $90 \mathrm{~min}$ in dark at room temperature. Gallic acid, $0.01-0.1 \mathrm{mg} / \mathrm{mL}$, was used to prepare a standard curve and data were expressed in milligram gallic acid equivalents (GAE)/ gram sample.

\section{Determination of individual phenolics using HPLC}

Briefly, extracts were filtered by $0.45-\mu \mathrm{m}$ membrane filters and introduced into a Waters 2695 HPLC (Waters Co., Milford, MA, USA) connected to a photodiode array (PDA) detector (Waters 2996). A Supelcosil LC-18 $25 \mathrm{~cm}$ $\times 4.60 \mathrm{~mm}, 5-\mu \mathrm{m}$ column (Sigma-Aldrich) was used as the stationary phase. Two different mobile phases were used: mobile phase A, double distilled water with $0.1 \%$ $(\mathrm{v} / \mathrm{v})$ trifluoroacetic acid (TFA) and mobile phase B, acetonitrile with $0.1 \%(\mathrm{v} / \mathrm{v})$ TFA. The linear gradient was used as follows: at $0 \mathrm{~min}, 95 \%$ solvent $\mathrm{A}$ and $5 \%$ solvent B; at $45 \mathrm{~min}, 65 \%$ solvent $\mathrm{A}$ and $35 \%$ solvent $\mathrm{B}$; at $47 \mathrm{~min}$, $25 \%$ solvent $A$ and $75 \%$ solvent $B$ and at 54 min turning into initial conditions. At a flow rate of $1 \mathrm{~mL} / \mathrm{min}, 10 \mu \mathrm{L}$ of sample was injected and spectral measurements were done at $280 \mathrm{~nm}, 312 \mathrm{~nm}$ and $360 \mathrm{~nm}$ (Kamiloglu et al., 2015a).

\section{Determination of total antioxidant activity/capacity}

\section{2,2'-Azino-bis(3-ethylbenzothiazoline-6-sulphonic acid (ABTS) radical scavenging assay}

ABTS assay was employed as described by Miller and Rice-Evans (1997). Shortly, $100 \mu \mathrm{L}$ of sample extract was mixed with $1 \mathrm{~mL}$ of $\mathrm{ABTS}^{+}$solution and after $1 \mathrm{~min}$, the absorbance was determined at $734 \mathrm{~nm}$ against the extraction solution. The standard was plotted with different concentrations of standard Trolox solution (0.01-0.1 $\mathrm{mg} / \mathrm{mL}$ ) instead of the sample extract. The control sample was generated using an equivalent amount of extraction solvent instead of sample.

\section{Cupric ion reducing antioxidant capacity (CUPRAC) assay}

The CUPRAC method was used as described by Apak et al. (2004). The reaction mixture was prepared using
1-mL $0.01 \mathrm{mM} \mathrm{CuCl}_{2}, 1-\mathrm{mL} 7.5 \mathrm{mM}$ neocuproine, 1-mL $1 \mathrm{M} \mathrm{NH}_{4}$ Ac $1-\mathrm{mL}$ water and $100-\mu \mathrm{L}$ extract. After mixing, the tube was incubated in dark for $30 \mathrm{~min}$ and the final absorbance was monitored spectrophotometrically at $450 \mathrm{~nm}$ against a reagent blank. Different concentrations of Trolox $(0.01-0.1 \mathrm{mg} / \mathrm{mL})$ were used for the preparation of standard curve. The total antioxidant capacity of samples was expressed as milligram of Trolox equivalent (TE)/gram sample.

\section{DPPH assay}

Briefly, $100 \mu \mathrm{L}$ of extract was added to $2 \mathrm{~mL}$ of $0.1 \mathrm{mM}$ DPPH in methanol solution. The reaction mixture was vortexed and kept in dark at room temperature for $30 \mathrm{~min}$ before measuring its absorbance at $515 \mathrm{~nm}$. The methanol solution was used as a blank (Kumaran and Karunakaran, 2006). A standard curve was plotted with Trolox $(0.01-0.1 \mathrm{mg} / \mathrm{mL})$ and total antioxidant capacity was expressed as milligram of TE/gram sample.

\section{Determination of antimicrobial activity}

Antimicrobial activity of garagurt was investigated by the Kirby-Bauer technique using the disc diffusion method on Mueller-Hilton agar (Oxoid CM337). The tested microorganisms (Listeria monocytogenes (ATCC 7644), Bacillus cereus (ATCC 11778), Staphylococcus aureus (ATCC 6538), Escherichia coli (ATCC 25292), Escherichia coli O157:H7 (ATCC 43894), Salmonella typhimurium (ATCC 14028), Pseudomonas fluorescens (ATCC 13525) and Yersinia enterocolitica (ATCC 23715) were spread on media by adjusting density at 0.5 McFarland. Twenty marmalade solutions were impregnated on 6-mm diameter paper discs (Oxoid CT0998B), and discs were placed on the media. Gentamicin $(10 \mu \mathrm{g}$, Oxoid CT0024B) was used as control. Antimicrobial activity was determined by measuring inhibition zones. Weak ( $\leq 12 \mathrm{~mm})$, medium $(12-16 \mathrm{~mm})$ and strong $(\geq 16$ $\mathrm{mm}$ ) was the scale used to evaluate the antimicrobial activity according to zone diameters (Bauer et al., 1966). All experiments were performed under aseptic conditions and as binary trials.

\section{Determination of minimum inhibitory concentration (MIC)}

The MIC was determined as described by the Institute of Clinical and Laboratory Standards (CLSI, 2012). Ten different concentrations $(1-512 \mu \mathrm{g} / \mathrm{mL})$ were tested by the MIC method; $100 \mu \mathrm{L}$ of serial dilutions and $5 \mu \mathrm{L}$ of bacterial solutions $(108 \mathrm{CFU} / \mathrm{mL})$ were added to the wells and incubated at $37 \pm 2{ }^{\circ} \mathrm{C}$ for $24 \mathrm{~h}$. One positive and one negative control well were used for each bacterium. 
MICs were determined by observing the lowest concentrations that completely inhibited the growth of microorganisms in micro-dilution wells.

\section{Results}

\section{Physicochemical composition}

The physicochemical composition of garagurt, including its $\mathrm{pH}$, total titratable acidity (citric acid equivalent), specific gravity, soluble dry matter, protein, ash, ascorbic acid and TPC as well as L, a and b values are shown in Table 1.

\section{Antioxidant activity}

The antioxidant activity of garagurt extract was analysed by employing three different methods. Antioxidant activities of the samples as determined by ABTS, CUPRAC and DPPH assays were 8,428 \pm 1,206 $\mathrm{mg}$ TE/100 g, 1,599 $\pm 41.4 \mathrm{mg} \mathrm{TE} / 100 \mathrm{~g}$ and $773 \pm 206 \mathrm{mg} \mathrm{TE} / 100 \mathrm{~g}$ respectively (Figure 2).

Table 1. Physicochemical properties of garagurt (Cornelian cherry marmalade).

\begin{tabular}{lc}
\hline $\mathrm{pH}$ & 2.04 \\
Total titratable acidity $(\mathrm{g} / 100 \mathrm{~mL})^{1}$ & 1.98 \\
Specific gravity $\left(\mathrm{g} / \mathrm{cm}^{3}, 20^{\circ} \mathrm{C}\right)$ & 1.3052 \\
Soluble dry matter $\left({ }^{\circ} \mathrm{Brix}\right)$ & 53.2 \\
Protein $(\% \mathrm{~N} \times 6.25)$ & 1.78 \\
Ash $(\%)$ & 2.32 \\
Ascorbic acid $(\mathrm{mg} / 100 \mathrm{~g})$ & 48 \\
Total phenolic content $(\mathrm{mg} \mathrm{GAE} / 100 \mathrm{~g})$ & $195 \pm 6.35$ \\
$\mathrm{~L}$ & 9.35 \\
$\mathrm{a}$ & 7.12 \\
$\mathrm{~b}$ & 7.22 \\
\hline \multirow{2}{*}{ Citric acid equivalent. }
\end{tabular}

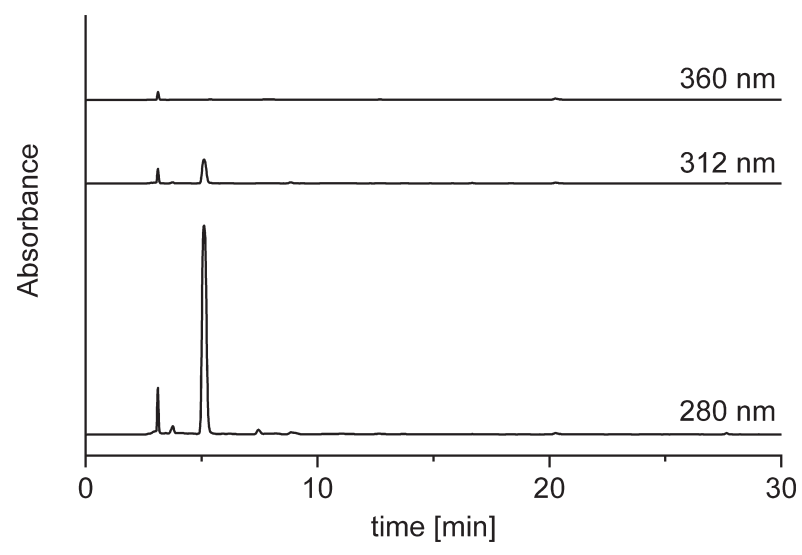

Figure 2. HPLC chromatograms of garagurt extract at $280 \mathrm{~nm}$, $312 \mathrm{~nm}$ and $360 \mathrm{~nm}$.

\section{Phenolic profile of garagurt extract}

The phenolic compounds in the samples were identified at the wavelengths of $280 \mathrm{~nm}, 312 \mathrm{~nm}$ and $360 \mathrm{~nm}$ by comparison with absorbance spectrum. Related chromatograms and the concentrations of identified phenolic compounds are presented in Figure 2 and Table 2 respectively.

\section{Antimicrobial activity of extracts}

The antimicrobial activity of garagurt, which had 0.66 $\mathrm{mg} / \mathrm{g}$ total phenol compounds, was tested on 3 gram-positive and 5 gram-negative microorganisms, which are important food pathogens (Table 3). Gentamicin $(10 \mu \mathrm{g})$ discs were used as positive controls. Although antimicrobial activity of the sample was weak against E. coli, E. coli O157:H7 and S. typhimurium, it had strong antimicrobial activities against $S$. aureus, $Y$. enterocolitica, $P$. fluorescens, L. monocytogenes and B. cereus.

\section{Minimum Inhibitory Concentration of extract}

The lowest concentration of garagurt, which has completely inhibited the bacterial growth, was determined as MIC value (Table 4). Although MIC values of garagurt

Table 2. Specific phenolic compounds identified and their quantities in garagurt extract.

\begin{tabular}{|c|c|c|c|}
\hline Absorbance & $\begin{array}{l}\text { Retention } \\
\text { time (min) }\end{array}$ & Component & $\begin{array}{l}\text { Concentration } \\
(\mathrm{mg} / 100 \mathrm{~g})\end{array}$ \\
\hline $280 \mathrm{~nm}$ & $3.67-3.75$ & Gallic acid & $33.4 \pm 2.24$ \\
\hline $280 \mathrm{~nm}$ & 20.2 & Ellagic acid & $16.9 \pm 2.04$ \\
\hline $280 \mathrm{~nm}$ & $27.58-27.64$ & Catechin derivative & $12.6 \pm 0.97$ \\
\hline $312 \mathrm{~nm}$ & 16.664 & $p$-Coumaric acid & $1.40 \pm 0.07$ \\
\hline $312 \mathrm{~nm}$ & 18.339 & $\begin{array}{l}p \text {-Coumaric acid } \\
\text { derivative }\end{array}$ & $1.00 \pm 0.02$ \\
\hline $360 \mathrm{~nm}$ & 25.83 & Rutin & $0.70 \pm 0.12$ \\
\hline
\end{tabular}

Table 3. Inhibition diameter zones $(\mathrm{mm})$ on the tested bacteria of garagurt.

\begin{tabular}{lcc} 
The tested bacteria & \multicolumn{2}{c}{ Zone of inhibition ( $\mathbf{m m})$} \\
\cline { 2 - 3 } & $\begin{array}{c}\mathbf{5 1 2} \mathbf{~} \mathbf{g} / \mathbf{m L} \text { of } \\
\text { garagurt }\end{array}$ & $\begin{array}{c}\text { Gentamicin } \\
\mathbf{1 0} \mathbf{~} \mathbf{g}\end{array}$ \\
\hline Listeria monocytogenes & 18 & 18 \\
Bacillus cereus & 17 & 25 \\
Staphylococcus aureus & 25 & 25 \\
Yersinia enterocolitica & 22 & 25 \\
Salmonella typhimurium & 10 & 19 \\
Escherichia coli & 12 & 20 \\
Escherichia coli O157:H7 & 12 & 13 \\
Pseudomonas fluorescens & 20 & 24 \\
\hline
\end{tabular}


Table 4. Minimum inhibitory concentrations (MIC) of garagurt against the tested bacteria.

\begin{tabular}{lccccccc} 
The tested bacteria & 512 & 256 & 128 & 64 & 32 & 16 & Gentamicin $(80 \mathrm{mg} / \mathrm{mL})$ \\
\hline Listeria monocytogenes & - & + & + & + & + & + & 0.003906 \\
Bacillus cereus & + & + & + & + & + & + & 0.001953 \\
Staphylococcus aureus & - & + & + & + & + & + & 0.000976 \\
Yersinia enterocolitica & - & + & + & + & + & + & 0.003906 \\
Salmonella typhimurium & + & + & + & + & + & + & 0.000976 \\
Escherichia coli & - & + & + & + & + & + & 0.003906 \\
Escherichia coli O157:H7 & + & + & + & + & + & + & 0.003906 \\
Pseudomonas fluorescens & - & + & + & + & + & + & 0.003906 \\
\hline
\end{tabular}

(0.66 mg phenol compound/g) were $\geq 256 \mathrm{mg} / \mathrm{mL}$ for L. monocytogenes, S. aureus, Y. enterocolitica, E. coli and $P$. fluorescens, reproduction was observed in all dilutions of B. cereus, S. typhimurium and E. coli O157:H7.

\section{Discussion}

\section{Physicochemical composition}

In a previous study, the $\mathrm{pH}$ and titratable acidity were reported as 2.09 and 2.1\%, respectively, in Cornelian cherry concentrate (Bozdogan, 2017) and 2.68-2.80 and $1.39-2.00 \%$, respectively, in its marmalade (Kökosmanlı and Keleş, 2000). The specific gravity and soluble dry matter content obtained in this study were higher than those for Cornelian cherry concentrate and marmalade reported in literature (Bozdoğan, 2017; Kökosmanlı and Keleş, 2000). Garagurt is a traditional product that was heat-treated for longer periods $(10 \mathrm{~h})$. Increase in soluble dry matter as a result of the concentration of the product also affects its density. Cornelian cherry fruits have been reported as a rich source of ascorbic acid (Tural and Koca, 2008) but decreases as a result of processing during marmalade or pulp production (Bozdoğan, 2017; Kökosmanlı and Keleş, 2000). The L, a, b values for garagurt were 9.35, $7.12,7.22$ respectively. In a previous study, similar values for $L$ (9.22), a (7.14) and b (7.02) have been reported for the Cornelian cherry concentrate (Bozdoğan, 2017).

\section{Total Phenolic Content}

Cosmulescu et al. (2019) reported TPC values between 163.69 and $359.28 \mathrm{mg}$ GAE/100 g, FW for wild Cornelian cherry genotypes. In another study, TPC of polar fraction and methanolic extract for fresh Cornelian cherry was determined as $439.9 \pm 34.6 \mathrm{mg} \mathrm{GAE} / 100 \mathrm{~g}$ and 2,110 \pm $84.0 \mathrm{mg}$ GAE/100 g respectively (Karaaslan et al., 2018). Similarly, Stankovic et al. (2014) reported the TPC values of different parts of Cornelian cherry (leaf, flower and fruits) ranging between 34,109 and 1,277 mg GAE/100 g. It has been suggested by previous studies that non-polar fractions of fresh Cornelian cherry extracts have higher
TPC compared to polar fractions of their extracts (Caillet et al., 2012). While Tural and Koca (2008) reported TPC of Cornelian cherry fruits changing from 2.81-5.79 mg GAE/g, Horasan Sağbasan (2015) determined this value as $1081.9 \mathrm{mg}$ GAE/100 g. Capanoglu et al. (2011) also reported TPC of fruits as $4918.8 \mathrm{mg}$ GAE/100 g dry weight (DW). The reason for differences in TPC in these studies could be related to the types of fruits used, the degree of maturity, different extraction methods and different solutions used for extraction. Lower TPC for garagurt in comparison to fresh Cornelian cherry could be related to the degradation of phenolic compounds due to heat treatment or exposure to sunlight during the sun-drying of marmalade. Likewise, Caillet et al. (2012) suggested that juice processing of cranberries could result in lower TPC of the final product.

Şengül et al. (2018) determined TPC, phenolic composition and antioxidant activity of traditionally produced Cornelian cherry marmalade. Their TPC result $(64.67 \mu \mathrm{g} /$ GAE g) was lower than our result. Kamiloglu et al. (2015b) determined TPC, antioxidant activity and phenolic acids in black carrot jams and marmalades. Jam and marmalade processing significantly reduced TPC, antioxidant activity and phenolic acids as between $89.2 \%$ and $90.5 \%$, $83.3 \%$ and $91.3 \%$, and $49.5 \%$ and $96.7 \%$ respectively. However, processing of black carrot to jam and marmalade caused increase in the recovery of bioaccessible TPC, phenolic acids and antioxidant activity in the range of $7.2-12.6 \%, 1.4-8.1 \%$ and $4.7-31.5 \%$ respectively.

Rababah et al. (2011) evaluated the effect of jam processing on some fruits with respect to their TPC, antioxidant capacity and anthocyanin content during 5 months of storage at $25{ }^{\circ} \mathrm{C}$. Jam processing reduced TPC, antioxidant capacity and anthocyanins of all fruits. Authors stated that despite decrement of TPC in jam processing, it could be considered as a suitable method to maintain the content of phenolics during storage. Howard et al. (2010) produced blueberry jams (sugar and sugar-free) and stored the samples for 6 months at $4{ }^{\circ} \mathrm{C}$ and $25{ }^{\circ} \mathrm{C}$. Although jam processing caused losses of anthocyanins, 
procyanidins, chlorogenic acid and oxygen radical absorbance capacity (ORAC) in both jam types, flavonols were retained well. Significant losses in anthocyanins and procyanidins occurred over 6-month storage. While chlorogenic acid content reduced during storage, flavonols and ORAC changed little. Jams stored at $4{ }^{\circ} \mathrm{C}$ retained higher amounts of anthocyanins, procyanidins and ORAC value than jams stored at $25^{\circ} \mathrm{C}$. Sugar-free jams retained higher amounts of anthocyanins than sugar-containing jams during late storage. They reported that blueberry jams should be cold-stored to better protect phenolic compounds and antioxidant activity. Even though the treatments used for jam and marmalade production caused reduction in TPC, flavonoids, ascorbic acid and carotenoids with respect to fresh fruits, it has been shown not to have a significant impact on the decline of antioxidant activity (Levaj et al., 2012; Rababah et al., 2011; Yildiz and Alpaslan, 2012).

\section{Antioxidant activity}

Şengül et al. (2018) determined antioxidant capacity (DPPH) of Cornelian cherry marmalade as $3.72 \%$. Hassanpour et al. (2011) found the total antioxidant activity of fresh Cornelian cherry fruit as $38.98-82.37 \%$. Many compounds that exhibit antioxidant effects are significantly degraded during food processing activities such as pasteurisation, sterilisation, dehydration, cooking and storage, and as a result, antioxidant activities are reduced. According to literature, antioxidant activities of foods decrease more during traditional production methods due to increase in applied temperature and processing time. Although the antioxidant activity of Cornelian cherry was not determined in the study conducted by Hassanpour et al. (2011), it was observed that the antioxidant capacity values reported for fresh Cornelian cherry fruits were higher than those determined in marmalade in the present study. It could be concluded that the lower antioxidant activity values in marmalades was due to the uncontrolled heat treatment conditions applied during marmalade production using a traditional method. Popović et al. (2012) reported considerable variation among Cornus mas genotypes in terms of antioxidant capacity. DPPH and ABTS values of acetone extracts of Cornus mas determined by Karaaslan et al. (2018) were $1,053 \pm 38.1 \mathrm{mg} \mathrm{TE} / 100 \mathrm{~g}$, FW and 2,907 $\pm 152 \mathrm{mg} \mathrm{TE} / 100$ g, FW respectively. Cosmulescu et al. (2019) reported the antioxidant activities of six Cornelian cherry types. Their DPPH results varied between 1.24 and $2.71 \mathrm{mmol}$ Trolox/100 g, FW. Horasan Sağbasan (2015) analysed the antioxidant activity of Cornelian cherry by DPPH, ABTS, CUPRAC and ferric-reducing antioxidant power (FRAP) assays, reported as 144.4, 124, 352.2 and $103.3 \mu \mathrm{mol}$ Trolox/100 g respectively. Moldovan et al. (2017) reported ABTS radical scavenging activity of fresh Cornus mas samples as 2,420 $\mathrm{mg} \mathrm{TE} / \mathrm{L}$ and declared that heat treatment and high-temperature storage caused significant decrease in total antioxidant activity and total phenolic contents. Capanoglu et al. (2011) also studied the antioxidant activity of Cornelian cherries by ABTS, CUPRAC and FRAP assays and reported the values as 50.8, 76.3 and $22.3 \mathrm{~g} \mathrm{TE} / 100 \mathrm{~g}$, DW respectively. On the other hand, West et al. (2012) investigated the antioxidant potential of Cornelian cherry juice and puree prepared from different varieties. According to their results, Cornus mas puree showed higher ORAC and reducing power compared to Cornus officinalis juice. Petridis et al. (2010) studied the antioxidant capacity of Cornelian cherry and other fruits grown in northern Greece. Their results showed that Cornelian cherry fruits had the highest FRAP value (80.15- $\mu \mathrm{M}$ ascorbic acid equivalent (AAE)/g, DW), followed by jujube $(69.55 \mu \mathrm{M}$ AAE/g, DW), cherries $(32.60$ $\mu \mathrm{M}$ AAE/g, DW), black grapes (31.40 $\mu \mathrm{M} \mathrm{AAE} / \mathrm{g}, \mathrm{DW})$ and blackberry (26.10 $\mu \mathrm{M} \mathrm{AAE/g,} \mathrm{DW).} \mathrm{The} \mathrm{antioxidant}$ power of Cornelian cherry fruits depends on the genotype, as well as the geographical region and climate of the area where it is cultivated, and its ripeness level. For instance, total antioxidant activity of 24 genotypes of Cornelian cherry fruits grown in Samsun, Turkey displayed a wide range changing from 16.21-94.43 $\mu \mathrm{M}$ $\mathrm{AAE} / \mathrm{g}, \mathrm{FW}$ as measured with FRAP assay (Tural and Koca, 2008).

\section{Phenolic profile of garagurt extract}

The most common phenolic compound in the samples was determined as gallic acid. Phenolic compounds in fresh Cornelian cherry fruit are considered good radical scavengers (Caillet et al., 2012). It has been reported that strong antioxidant activities of fresh fruits are mostly caused by anthocyanins. However, no anthocyanin was detected in the garagurt sample, which could be due to the process effect.

Şengül et al. (2018) determined gallic acid, (+)catechin, (-)epicatechin, caffeic acid and ellagic acid in Cornelian cherry marmalade as $2.58,1.22,31.50,8.91$ and $2.40 \mathrm{mg} /$ $\mathrm{kg}$ respectively. Rutin was not determined. Gallic acid and ellagic acid contents in our sample were found to be higher compared with these results. Cosmulescu et al. (2019) also examined the phenolic compounds of wild Cornelian cherry fruit genotypes. Among the individual phenolic compounds, gallic acid was determined in higher amount $(14.49 \mathrm{mg} / 100 \mathrm{~g})$, followed by coumaric acid (13.79 mg/100 g), ellagic acid (5.71 mg/100 g), salicylic acid $(1.43 \mathrm{mg} / 100 \mathrm{~g})$, ferulic acid $(1.25 \mathrm{mg} / 100 \mathrm{~g})$ and synaptic acid $(0.19 \mathrm{mg} / 100 \mathrm{~g})$. MilenkovicAndjelkovic et al. (2015) indicated that ellagic acid was the predominant phenolic acid in Cornelian cherry fruit and leaf extracts, followed by chlorogenic and gallic acids. 
Pyrkosz-Biardzka et al. (2014) indicated the presence of pelargonidin 3-O-galactoside, cyanidin 3-O-galactoside and delphinidin 3-O-galactoside, myricetin (26.54 $\mathrm{mg} / 100 \mathrm{~g})$ and rutin $(3.07 \mathrm{mg} / 100 \mathrm{~g})$ in Cornelian cherry fruit. Rudrapaul et al. (2015) reported the presence of a new $\beta$-hydroxychalcone (4-acetoxy-5, $2^{\prime}, 4^{\prime}, 6^{\prime}, \beta$-pentahydroxy-3-methoxychalcone), a new flavanone (7,3'-dihydroxy-5,4'-dimethoxy flavanone) and seven known compounds: 2R, 3R-trans-aromadendrin, naringenin-7-O-methylether, myricetin, quercetin-3-O-rutinoside, ursolic acid, gallic acid and d-glucose in the methanolic extract of Cornelian cherry fruit. Wide variability was recorded for the same phenolic compound between different genotypes. The variation limits were quite high, indicating that the genotype and environmental factors are very critical for fruit composition. Moldovan et al. (2017) reported decreased antioxidant activities in fresh Cornelian cherry extracts stored at different temperatures and periods. These losses have been reported to be largely due to a decrease in the presence of anthocyanins (Pawlowska et al., 2010). Similarly, Kamiloglu et al. (2015b) reported that individual anthocyanins of black carrots were decreased up to $95 \%$ when they are processed into marmalade. Consequently, because the stability of anthocyanins depends on their types and source, Cornelian cherry anthocyanins could have been totally degraded during marmalade processing or their concentrations were lower than the limit of detection (LOD) of the used HPLC system. Factors such as Cornelian cherry genotype, ecological conditions of the region where the fruit is grown, cultivation technique, cultural measures, maturity level, transport, storage, differences in production methods of marmalades and differences in the methods used for extraction could affect the composition and antioxidant activity of Cornelian cherry marmalade.

\section{Antimicrobial activity of extracts}

There are some studies on the antimicrobial activity of Cornelian cherry fruit products obtained by different processing methods. Harich et al. (2017) reported that concentrated Cornelian cherry juice showed strong antimicrobial activity against E. coli $\mathrm{O} 157: \mathrm{H} 7$, L. monocytogenes and S. typhimurium using agar disc diffusion and MIC method. In another study, the same researchers reported that pressed Cornelian cherry fruit extracts have strong antimicrobial activity against E. coli, E. coli O157:H7. S. typhimurium, S. aureus, Y. enterocolitica, $P$. aerugionosa, $L$. monocytogenes and $B$. cereus according to MIC values; however, gram-positive microorganisms were more resistant against the Cornelian cherry puree extracts (Yiğit, 2018). The Cornelian cherry puree was used for the marination of pork meat, and the results indicated that reduction in the number of E. coli, S. enteritidis, L. monocytogenes and S. aureus was statistically significant (Gniewosz and Stobnicka, 2017). In our study, antimicrobial activity of garagurt was investigated by using the disc diffusion method as well as MIC dilution method. Although garagurt had weak antimicrobial activity against $S$. typhimurium, E. coli and E. coli $\mathrm{O} 157: \mathrm{H} 7$, strong antimicrobial activity was observed against L. monocytogenes, S. aureus, Y. enterocolitica and P. fluorescens. While $B$. cereus had a strong antimicrobial activity with $17-\mathrm{mm}$ zone in the disc diffusion method, MIC dilution proliferation was detected at $512 \mathrm{mg} / \mathrm{g}$ dilution. This situation can be explained by the loss of disc properties or the pseudo-resistance of microorganism to antibacterial agent (Arkkan and Uysal, 2005).

The findings of our study were compared with other researchers (Gniewosz and Stobnicka, 2017; Harich et al., 2017), and even though the antimicrobial activity was found to be similar to other studies (strong against L. monocytogenes, S. aureus and P. fluorescens), the results indicating a weak antimicrobial activity against $S$. typhimurium, E. coli and E. coli O157:H7 were not comparable. This could be explained by variability in phenolic compounds due to different fruit processing steps. In addition, there were $40-80$ times proportional differences in terms of active compounds between the antibiotic formulation which had the MIC values of the positive control gentamicin $(10 \mu \mathrm{g})$ used in MIC dilution $(0.001953-0.003906 \mathrm{mg} / \mathrm{g})$ and the ratio of total phenolic compounds in the dilution of $256 \mathrm{mg} / \mathrm{g}(0.165 \mathrm{mg})$ and the marmalade. It is necessary to investigate the possibilities of incorporation of Cornelian cherry fruit/extract as an antimicrobial agent by increasing active ingredient content by using different food processing techniques.

\section{Conclusion}

The main purpose of garagurt production is to transform fresh Cornelian cherry fruits into a stable product with long shelf life. Traditional Cornelian cherry marmalade known as garagurt has been used for centuries for the treatment of many diseases. To the best of our knowledge, this is the first research investigating the antioxidant and antimicrobial effects of garagurt, and our aim was to increase the knowledge on this traditional product. According to the results, the antioxidant activity of garagurt was not provided by anthocyanins; they were lost during heat treatment; instead, gallic acid and ellagic acid were found to be the main antioxidant substances. Although Cornelian cherry marmalade had poor antimicrobial activity against $S$. typhimurium, E. coli and E. coli O157:H7, strong antimicrobial activity was observed against L. monocytogenes, S. aureus, $Y$. enterocolitica and P. fluorescens. This traditional product could be used as an ingredient with its natural antimicrobial effect in the 
production of different foods and may have a positive effect to prolong shelf life. We conclude from the results that the consumption of garagurt might display a good antioxidant activity. However, further in vivo studies are recommended to confirm whether these in vitro activities could be confirmed in vivo. The future studies should also focus on identifying other specific phytochemicals in garagurt.

\section{Conflict of interest}

The authors have declared no conflict of interest in this article.

\section{Funding}

This study was supported by Scientific Research Projects Unit of Balıkesir University Grant No. BAP.2019/120.

\section{Compliance with Ethical Standards}

This article followed all ethical standards for a research without direct contact with human or animal subjects.

\section{References}

Alavian, S.M., Banihabib, N., Es Haghi, M. and Panahi, F., 2014. Protective effect of cornus mas fruits extract on serum biomarkers in $\mathrm{CCl}_{4}$-induced hepatotoxicity in male rats. Hepatitis Montly 14(4): e10330. https://doi.org/10.5812/hepatmon.10330

Apak, R., Güçlü, K., Özyürek, M. and Karademir, S.E., 2004. Novel total antioxidant capacity index for dietary polyphenols and vitamins $\mathrm{C}$ and $\mathrm{E}$ using their cupric ion reducing capability in the presence of neocuproine: CUPRAC method. Journal of Agricultural and Food Chemistry 52(26): 7970-7981. https://doi. org/10.1021/jf048741x

Arıkan, A.Ö. and Uysal,S., 2005. Evaluation of disk diffusion test for carbapenem sensitivity in acinetobacterbaumannii and pseudomonas aeruginosa strains. Mikrobiyology Bulten 39: 273-279.

Association of Official Analytical Chemists (AOAC), 1990. Official methods of analysis of the association of official analytical chemists, $15^{\text {th }}$ edition. AOAC, Washington, DC, USA.

Bauer, R.W., Kirby, M.D.K., Sherris, J.C. and Turck, M., 1966. Antibiotic susceptibility testing by a standardized single disk method. American Journal of Clinical Pathology 45: 493-496. https://doi.org/10.1093/ajcp/45.4_ts.493

Bernal, J., Mendiola, E. and Ibáñez, A., 2011. Cifuentes advanced analysis of nutraceuticals. Journal of Pharmaceutical and Biomedical Analysis 55: 758-774. https://doi.org/10.1016/j. jpba.2010.11.033

Bijelić, S.M., Gološin, B.R., Todorović, J.I.N., Cerović, S.B. and Popović, B.M., 2011. Physicochemical fruit characteristics of Cornelian cherry (Cornus mas L.) genotypes from
Serbia. Hortscience 46(6): 849-853. https://doi.org/10.15835/ nsb9410161

Bozdogan, A., 2017. Viscosity and physicochemical properties of Cornelian cherry (Cornus mas L.) concentrate. Food Measure 11: 1326-1332. https://doi.org/10.1007/s11694-017-9510-9

Caillet, S., Côté, J., Sylvain, J.F. and Lacroix, M., 2012a. Antimicrobial effects of fractions from cranberry products on the growth of seven pathogenic bacteria. Food Control 23: 419-428. https://doi. org/10.1016/j.foodcont.2011.08.010

Caillet, S., Lorenzo, G., Côté, J., Sylvain, J.F. and Lacroix, M., 2012b. Free radical-scavenging properties and antioxidant activity of fractions from cranberry products. Food and Nutrition Sciences 3: 337-347. https://doi.org/10.4236/ fns.2012.3304.9

Çakmakcl, S. and Tosun, M., 2010. Characteristics of mulberry pekmez with Cornelian cherry. International Journal of Food Properties 13: 713-722. https://doi.org/10,1080/ 10942910902804459

Capanoglu, E., Boyacioglu, D., de Vos R.C.H., Hall R.D. and Beekwilder, J., 2011. Procyanidins in fruit from sour cherry (Prunuscerasus) differ strongly in chain length from those in laurel cherry (Prunuslauracerasus) and cornelian cherry (Cornus mas). Journal of Berry Research 1: 137-146. https://doi.org/10.3233/ BR-2011-015

Çelik, F., 2009. Kızılcığın (Cornus mas L.) ekstraksiyonu ve Antioksidan bileşenlerinin analizi, Enstitüsü Kimya Anabilimdalı, Selçuk Üniversitesi Fen Bilim Leri, Konya, p. 88.

Celik, S., Bakirci, I. and Suat, I.G., 2006. Physicochemical and organoleptic properties of yogurt with Cornelian cherry paste, International Journal of Food Properties 9: 401-408. https://doi. org/10.1080/10942910600596258

Cetkovska, J., Divis, P., Vespalcova, M., Porizka, J. and Reznicek, V., 2015. Basic nutritional properties of Cornelian cherry (Cornus mas L.) cultivars grown in the Czech Republic. Actaalimentaria 44: 549-557. https://doi.org/10.1556/AAlim.2014.0013

Clinical and Laboratory Standards Institute (CLSI), 2012. Antimicrobial susceptibility testing standards. Available at: https://clsi.org/media/2663/m100ed29_sample.pdf.

Coşkun, F., 2006. Gıdalarda bulunan doğal koruyucular. Gida Teknolojileri Elektronik Dergisi 2: 27-33. ISSN: 1306-7648.

Cosmulescu, S., Trandafir, I. and Cornescu, F., 2019. Antioxidant capacity, total phenols, total flavonoids and colour component of Cornelian cherry (Cornus mas L.) wild genotypes. Notulae Botanicae Horti Agrobotanici Cluj-Napoca 47(2): 390-394. https://doi.org/10.15835/nbha47111375

Côté, J., Caillet, S., Doyon, G., Dussault, D., Sylvain, J.-F. and Lacroix, M., 2011. Antimicrobial effect of cranberry juice and extracts. Food Control 22: 1413-1418. https://doi.org/10.1016/j. foodcont.2011.02.024

Czerwin'ska, M.E. and Melzig, M.F., 2018. Cornus mas and Cornusofficinalis-Analogies and differences of two medicinal plants traditionally used. Frontiers in Pharmacology 9: 894. https://doi.org/10.3389/fphar.2018.00894.

David, L. and Moldovan, B., 2015. Extraction, characterization and potential health benefits of bioactive compounds from selected Cornus fruits. In: Fruits and pomace extracts: biological activity, 
potential applications and beneficial health effects. Nova Science, New-York, NY, USA, pp. 157-188.

Demir, F. and Kalyoncu, I.H., 2003. Some nutritional, pomological and physical properties of Cornelian cherry (Cornus mas L.). Journal of Food Engineering 60: 335-341. https://doi.org/10.1016/ S0260-8774.(03)00056-6

Deng, S., West, B.J. and Jensen, C.J., 2013. UPLC-TOF-MS characterization and identification of bioactive iridoids in Cornusmas fruit. Journal of Analytical Methods in Chemistry 2013: 1-7. https://doi.org/10.1155/2013/710972

Dinda, B., Kyriakopoulosb A.M., Dinda S., Zoumpourlis V., Thomaidis N.S., Velegraki A., Markopoulos C. and Dinda, M., 2016. Cornus mas L. (Cornelian cherry), an important European and Asian traditional food and medicine: ethnomedicine, phytochemistry and pharmacology for its commercial utilization in drug industry. Journal of Ethnopharmacology 193: 670-690. https://doi.org/10.1016/j.jep.2016.09.042

Drkenda, P., Spahić, A., Begić-Akagić, A., Gaši, F., Vranac, A., Hudina, M. and Blanke, M., 2014. Pomological characteristics of some autochthonous genotypes of Cornelian cherry (Cornus mas L.) in Bosnia and Herzegovina. Erwerbs-Obstbau 56: 59-66. https://doi.org/10.1007/s10341-014-0203-9

Ercisli, S., Yılmaz, S.O., Gadze, J., Dzubur, A., Hadziabulic, S. and Aliman, J., 2011. Some fruit characteristics of Cornelian cherries (Cornus mas L.). Notulae Botanicae Horti Agrobotanici ClujNapoca 39: 255-259. https://doi.org/10.15835/nbha3915875

Gniewosz, M. and Stobnicka, A., 2017. Bioactive components content, antimicrobial activity, and foodborne pathogen control in minced pork by cranberry pomace extracts. Journal of Food Safety 38(1): e12398. https://doi.org/10.1111/jfs.12398

Gunduz, K., Saracoglu, O., Ozgen, M. and Serce, S., 2013. Antioxidant, physical and chemical characteristics of Cornelian cherry fruits (Cornus mas L.) at different stages of ripeness. ACTA Scientiarum Polonorum Horticulture 12: 59-66.

Güneş, N.T., Özüpek, Ö. and Bakoglu, N., 2016. Amasya'daDoğal Olarak Yetişen Kızılcık (Cornus mas L.) Meyvelerinin Raf Ömrü Sürecinde Bazı Fizikokimyasal Özelliklerindeki Değişim Ler. Bahçe, Yalova Atatürk Bahçe Kültürleri Merkez Araştırma Enstitüsü Dergisi 45(1): 680-684.

Harich, M., Maherani, B., Salmieri, S. and Lacroix, M., 2017. Antibacterial activity of cranberry juice concentrate on freshness and sensory quality of ready to eat (RTE) foods. Food Control 75: 134-144. https://doi.org/10.1016/j.foodcont.2016.11.038

Hassanpour, H., Yousef, H., Jafar, H. and Mohammad, A., 2011. Antioxidant capacity and phytochemical properties of Cornelian cherry (Cornus mas L.) genotypes in Iran. Scientia Horticulturae 129: 459-463. https://doi.org/10.1016/j.scienta.2011.04.017

Horasan Sağbasan, B., 2015. Investigating the bioaccesibility of antioxidants in red fruits commonly consumed in Turkey. Master's thesis, Department of Food Engineering, ITU Institude of Natural and Applied Sciences, p. 105.

Hosseinpour-Jaghdani, F., Shomali, T., Gholipour-Shahraki, S., Rahimi-Madiseh, M. and Rafieian-Kopaei, M., 2017. Cornus mas: a review on traditional uses and pharmacological properties. Journal of Complementary and Integrative Medicine 14(3). https://doi.org/10.1515/jcim-2016-0137
Howard, L.R., Castrodale, C., Brownmiller, C. and Mauromoustakos, A., 2010. Jam processing and storage effects on blueberry polyphenolics and antioxidant capacity. Journal of Agricultural and Food Chemistry 58: 4022-4029. https://doi.org/10,1021/jf902850h

Jayaprakasam, B., Vareed, S.K., Olson, L.K. and Nair, M.G., 2005. Insulin secretion by bioactive anthocyanins and anthocyanidins present in fruits. Journal of Agricultural and Food Chemistry 53: 28-31. https://doi.org/10.1155/2015/939402

Kalyoncu, İ.H., Ersoy, N. and Yllmaz, M., 2009. Physico-chemical and nutritional properties of Cornelian cherry fruits (Cornus mas L.) grown in Turkey. Asian Journal of Chemistry 21(8): 6555-6561.

Kamiloglu, S., Pasli, A.A., Ozcelik, B., Camp, J.V. and Capanoglu, E., 2015a. Colour retention, anthocyanin stability and antioxidant capacity in black carrot (Daucuscarota) jams and marmalades: effect of processing, storage conditions and in vitro gastrointestinal digestion. Journal of Functional Foods 13: 1-10. https://doi. org/10.1016/j.jff.2014.12.021

Kamiloglu, S., Pasli, A.A., Ozcelik, B., Van Camp, J. and Capanoglu, E., 2015b. Influence of different processing and storage conditions on in vitro bioaccessibility of polyphenols in black carrot jams and marmalades. Food Chemistry 186: 74-82. https://doi. org/10.1016/j.foodchem.2014.12.046

Karaaslan, M.G., Karaaslan, N.M. and Ates, B., 2018. Investigation of mineral components and antioxidant properties of a healthy red fruit: Cornelian cherry (Cornus mas L.). Journal of the Turkish Chemical Society Section A: Chemistry 5(3): 1319-1326. https:// doi.org/10.18596/jotcsa.449593

Kazimierski, M., Regula, J. and Molska, M., 2019. Cornelian cherry (Cornus mas L.) - characteristics, nutritional and pro-health properties. Acta Scientiarum Polonorum Technologia Alimentaria 18(1): 5-12. https://doi.org/10.17306/J.AFS.2019.0628

Kökosmanll, M. and Keleş, F., 2000. The possibilities of Cornelian cherry fruits grown in Erzurum by processing into the marmalade and pulp products. Food 25(4): 289-298.

Kubola, J., Siriamornpun, S. and Meeso, N., 2011. Phytochemicals, vitamin $\mathrm{C}$ and sugar content of Thai wild fruits. Food Chemistry 126: 972-981. https://doi.org/10.1016/j.foodchem.2010.11.104.

Kucharska, A.Z., 2012. Active compounds of Cornelian cherry fruit (Cornus mas L.). Wydawnictwo Uniwersytetu Przyrodniczego (UWP), Wrocław, Poland.

Kucharska, A.Z., Sokół-Łetowska, A. and Piórecki, N., 2011. Morphological, physical \& chemical, and antioxidant profiles of polish cultivars of Cornelian cherry fruit (Cornus mas L.). Zywnosc Nauka Technologia Jakosc 3: 78-89. https://doi. org/10.15193/zntj/2011/76/078-089

Kumaran, A. and Karunakaran, R.J., 2006. Nitric Oxide Radical Scavenging Active Components From Phyllanthus emblica L. Plant Foods for Human Nutrition 61: 1. https://doi.org/10.1007/ s11130-006-0001-0

Levaj, B., Kovačević, D. B., Bituh, M. and Dragović-Uzelac, V., 2012. Influence of jam processing upon the contents of phenolics and antioxidant capacity in strawberry fruit (Fragariaananassa $x$ Duch.). Croatian Journal of Food Technology Biotechnology and Nutrition 7: 18-22. https://hrcak.srce.hr/82765

Milenkovic-Andelkovic, A.S., Andelkovic, M.Z., Radovanovic, A.N., Radovanovic, B.C. and Nikolic, V., 2015. Phenol composition, 
DPPH radical scavenging and antimicrobial activity of Cornelian cherry (Cornus mas) fruit and leaf extracts. HemijskaIndustrija 69(4): 331-337. https://doi.org/10,2298/HEMIND14021604.6M

Miller, N.J. and Rice-Evans, C.A., 1997. Factors influencing the antioxidant activity determined by the ABTS+ radical cation assay. Free Radical Research 26(3): 195-199. https://doi. org/10.3109/10715769709097799

Mohebbi, S., Mostof, Y., Zamani, Z. and Najafi, F., 2015. Influence of modified atmosphere packaging on storability and post-harvest quality of Cornelian cherry (Cornus mas L.) fruits. Notulae Scientia Biologicae 7(1): 116-122. https://doi.org/10.15835/ nsb.7.1.9397

Moldovan, B. and David, L., 2014. Influence of temperature and preserving agents on the stability of Cornelian cherries anthocyanins. Molecules 19: 8177-8188. https://doi.org/10.3390/ molecules19068177

Moldovan, B., David, L., Achim, M., Clichici, S. and Filip, G.A., 2016a. A green approach to phytomediated synthesis of silver nanoparticles using Sambucus nigra L. fruits extract and their antioxidant activity. Journal of Molecular Liquids 221: 271-278. https://doi.org/10.1016/j.molliq.2016.06.003

Moldovan, B., David, L. and Man, S.C., 2017. Impact of thermal treatment on the antioxidant activity of Cornelian cheries extract. Studia Ubb Chemia LXII(2): 311-317. https://doi.org/10.24193/ subbchem.2017.2.24

Moldovan, B., Filip, A., Clichici, S., Suharoschi, R., Bolfa, P. and David, L., 2016b. Antioxidant activity of Cornelian cherry (Cornus mas $L$.) fruits extract and the in vivo evaluation of its anti-inflammatory effects. Journal of Functional Foods 26: 77-87. https://doi. org/10.1016/j.jff.2016.07.004

Mustafa, B., Hajdari, A., Krasniqi, F., Hoxha, E., Ademi, H., Quave, C.L. and Pieroni, A., 2012. Medical ethnobotany of the Albanian Alps in Kosovo. Journal of Ethnobiology and Ethnomedicine 8: 6. https://doi.org/10.1186/174.6-4269-8-6

Moldovan,B., Filip, A., Clichici,S., Suharoschi,R., Bolfa, P. and David, L. 2016. Antioxidant activity of Cornelian cherry (Cornus mas L.) fruits extract and the in vivo evaluation of its antiinflammatory effects. Journal of Functional Foods 26: 77-87. https://doi. org/10.1016/j.jff.2016.07.004

Ozgen, F., 2015. Experimental investigation of drying characteristics of Cornelian cherry fruits (Cornus mas L.). Heat and Mass Transfer 51: 343-352. https://doi.org/10.1007/s00231-014-1397-y

Pawlowska, A.M., Camangi, F. and Braca, A., 2010. Qualiquantitative analysis of flavonoids of Cornus mas L. (Cornaceae) fruits. Food Chemistry 119: 1257-1261. https://doi.org/10.1016/j. foodchem.2009.07.063

Petridis, A., Koukourikou, M., Sotiropoulos, T. and Stylianidis, D., 2010. Antioxidant activity of fruits produced in northern Greece. Hort Science 45(9): 1341-1344. https://doi.org/10.21273/ HORTSCI.45.9.134.1

Polat, R., Cakilcioglu, U. and Satil, F., 2013. Traditional uses of medicinal plants in Solhan (Bingol-Turkey). Journal of Ethnopharmacology 148: 951-963. https://doi.org/10.1016/j. jep.2013.05.050

Popović, B.M., Štajner, D., Slavko, K. and Sandra, B., 2012. Antioxidant capacity of Cornelian cherry (Cornus mas
L.)-Comparison between permanganate reducing antioxidant capacity and other antioxidant methods. Food Chemistry 134(2): 734-741. https://doi.org/10.1016/j.foodchem.2012. 02.170

Pyrkosz-Biardzka, K., Kucharska, A.Z., Sokol-Letowska, A., Strugala, P. and Gabrielska, J., 2014. A comprehensive study on antioxidant properties of crude extracts from fruits of Berberisvulgaris L. Cornus mas L. and Mahoniaaquifolium Nutt. Polish Journal of Food and Nutrition Sciences 64(2): 91-99. https://doi. org/10.2478/v10222-012-0097-x

Rababah, T.M., Al-Mahasneh, M.A., Kilani, I., Yang, W., Alhamad, M.N., Ereifej, K. and Al-U'datt, M., 2011. Effect of jam processing and storage on total phenolics, antioxidant activity, and anthocyanins of different fruits. Journal of the Science of Food and Agriculture 91: 1096-1102. https://doi.org/10.1002/jsfa.4289

Rababah, T.M., Al-u'datt, M., Almajwal, A., Brewer, S., Feng, H., Al-Mahasneh, M., Ereifej, K. and Yang, W., 2012. Evaluation of the nutraceutical, physiochemical and sensory properties of raisin jam. Journal of Food Science 77: 609-613. https://doi. org/10.1111/j.1750-3841.2012.02708.x

Rangkadilok, N., Sitthimonchai, S., Worasuttayangkurn, L., Mahidol, C., Ruchirawat, M. and Satayavivad, J., 2007. Evaluation of free radical scavenging and antityrosinase activities of standardized longan fruit extract. Food and Chemical Toxicology 45: 328-336. https://doi.org/10.1016/j.fct.2006.08.022

Rosa, A., Atzeri, A., Deiana, M., Scano, P., Incani, A., Piras, C. and Marincola, F.C., 2015. Comparative antioxidant activity and $1 \mathrm{H}$ NMR profiling of Mediterranean fruit products. Food Research International 69: 322-330. https://doi.org/10.1016/j. foodres.2015.01.001

Rudrapaul, P., Kyriakopoulos, A.M., De U.C., Zoumpourlis, V. and Dinda B., 2015. New flavonoids from the fruits of Cornus mas, Cornaceae. Phytochemistry Letters 11: 292-295. https://doi. org/10.1016/j.phytol.2015.01.011

Seeram, N.P., Schutzki, R., Chandra, A. and Nair, M.G., 2002. Characterization, quantification and bioactivities of anthocyanins in Cornus species. Journal of Agricultural and Food Chemistry 50: 2519-2523. https://doi.org/10,1021/jf0115903

Şengül, M., Topdaş, E.F., Doğan, H. and Serencam, H., 2018. Some physical and chemical properties, antioxidant activities and phenolic profiles of different marmalades traditionally produced in Artvin, Turkey. Akademik Gida 16(1): 51-59. https://doi. org/10.24323/akademik-gida.415888

Şengün, İ.Y. and Yücel, E., 2015. Antimicrobial properties of wild fruits. Biological Diversity and Conservation 8(1): 69-77. https:// doi.org/10.24323/akademik-gida.544831

Serteser, A., Kargığlu, M., Gök, V., Bağcı, Y., Özcan, M. and Arslan, D., 2009. Antioxidant properties of some plants growing wild in Turkey. Grasas Aceites 60: 147-154. https://doi.org/10.3989/ gya.086208

Shahidi, F. and Naczk, M., 1995. Food phenolics: sources, chemistry, effects and applications. Technomic, Lancaster, UK.

Spanos, G.A. and Wrolstad, R.E., 1990. Influence of processing and storage on the phenolic composition of Thompson seedless grape juice. Journal of Agricultural and Food Chemistry 38(7): 1565-1571. https://doi.org/10.1021/jf00097a030 
Stankovic, M.S., Zia-Ul-Haq, M., Bojovic, B.M. and Topuzovic, M.D., 2014. Total phenolics, flavonoid content and antioxidant power of leaf, flower and fruits from Cornelian cherry (Cornus mas L.). Bulgarian Journal of Agricultural Science 20(2): 358-363.

Szumny, D., Sozanski, T., Kucharska A.Z., Dziewiszek W., Piórecki N., Magdalan J., Ewa Chlebda-Sieragowska E., Kupczynski R., Szeldg A. and Szumny A., 2015. Application of Cornelian cherry iridoid-polyphenolic fraction and loganic acid to reduce intraocular pressure. Evidence-Based Complementary and Alternative Medicine Article ID 939402: 8. https://doi. org/10.1155/2015/9394.02

Tontul, I., Eroğlu, E. and Topuz, A., 2018. Convective and refractance window drying of Cornelian cherry pulp: effect on physicochemical properties. Journal of Food Process Engineering 41: e12917. https://doi.org/10.1111/jfpe.12917

Topdaş, E.F., Çakmakçı, S. and Çakıroğlu, K., 2017. The antioxidant activity, vitamin $\mathrm{C}$ contents, physical, chemical and sensory properties of ice cream supplemented with Cornelian cherry (Cornus mas L.) paste. Kafkas Universitesi Veteriner Fakültesi Dergisi 23(5): 691-697. https://doi.org/10.9775/ kvfd.2016.17298

Tural, S. and Koca, I., 2008. Physico-chemical and antioxidant properties of Cornelian cherry fruits (Cornus mas L.) grown in Turkey. Scientia Horticulturae 116: 362-366. https://doi.org/10.1016/j. scienta.2008.02.003

Turkish Statistical Institute (TUIK), 2018. Plant production statistics. TUIK, Ankara, Turkey. Available at: https://ec.europa.eu > eurostat > documents > Turkey.

Uylaşer, V. and Başoğlu F., 2016. Basic Food Analyses. ISBN-10: 6059666388, ISBN-13: 978-6059666381, Dora, p. 135.

Vardin, A.M., Khordadmehr, M., Heidari, R., Hedaiat-o-llah, N.H., Amirkhiz, M.B. and Abbasi, M.M., 2018. The effects of cornusmas hydro-methanolic extract on cisplatin-induced nephrotoxicity in rats. Pharmaceutical Sciences 24: 97-103. https://doi.org/10.15171/PS.2018.15

Vareed, S.K., Reddy, M.K., Schutzki, R.E. and Nair, M.G., 2006. Anthocyanins in Cornusalternifolia, Cornuscontroversa, Cornuskousa and Cornusfloridafruits with health benefits. Life Sciences 78: 777-784. https://doi.org/10.1016/j.lfs.2005.05.094

West, B.J., Deng, S., Jensen, C.J., Palu, A.K. and Berrio, L.F., 2012. Antioxidant, toxicity, and iridoid tests of processed Cornelian cherry fruits. International Journal of Food Science and Technology 47(7): 1392-1397. https://doi. org/10.1111/j.1365-2621.2012.02985.x

Wu, V.C.H., Qiu, X., Bushway, A. and Harper, L., 2008. Antibacterial effects of American cranberry (Vacciniummacrocarpon) concentrate on food-borne pathogens. LWT-Food Science and Technology 41: 1834-1841. https://doi.org/10.1016/j.lwt.2008.01.001

Xi, Y., Yu, M., Godoy, R., Hatch, G., Poitras, L. and Ekker, M., 2011. Transgenic zebrafish expressing green fluorescent protein in dopaminergic neurons of the ventral diencephalon. Developmental Dynamics 240(11): 2539-2547. https://doi. org/10.1002/dvdy.22742

Yigit, D., 2018. Antimicrobial and antioxidant evaluation of fruit extract from Cornus mas L. Aksaray University Journal of Science and Engineering 2(1): 41-51. https://doi.org/10.29002/ asujse.329856

Yildiz, O. and Alpaslan, M., 2012. Properties of Rose Hip Marmalades. Food Technology and Biotechnology 50: 98-106.

Yılmaz, K.U., Ercisli, S., Zengin, Y., Sengul, M. and Kafkas, E.Y., 2009. Preliminary characterization of Cornelian cherry (Cornus mas L.) genotypes for their physico-chemical properties. Food Chemistry 114: 408-412. https://doi.org/10.1016/j.foodchem.2008.09.055

Zargari, A., 1996. Medicinal plants (in Persian), vol. 3, $6^{\text {th }}$ edition. Tehran University Press, Tehran, Iran, p. 538.

Zargari, A., 1997. Medicinal plants, part B. Tehran University Press, Tehran, Iran, pp. 643-645. 